Article

\title{
Optimization of Pre-Treatment Process Parameters to Generate Biodiesel from Microalga
}

\author{
Chukwuma Onumaegbu ${ }^{1}$, Abed Alaswad ${ }^{2}$, Cristina Rodriguez ${ }^{1}$ and Abdul G. Olabi ${ }^{1, *}$ \\ 1 Institute of Engineering and Energy Technologies, School of Engineering and Computing, the University of \\ the West of Scotland, Paisley PA1 2BE, UK; chukwuma.onumaegbu@uws.ac.uk (C.O.); \\ cristina.rodriguez@uws.ac.uk (C.R.) \\ 2 School of Engineering and the Built Environment, Birmingham City University, Birmingham B5 5JU, UK; \\ abed.alaswad@bcu.ac.uk \\ * Correspondence: abdul.olabi@uws.ac.uk; Tel.: +44-1418-483-450
}

Received: 1 March 2018; Accepted: 29 March 2018; Published: 31 March 2018

check for updates

\begin{abstract}
Cell disruption is an integral part of microalga production process, which improves the release of intracellular products that are essential for biofuel production. In this work, pre-treatment parameters that will enhance the efficiency of lipid production using high-pressure homogenizer on microalgae biomass will be investigated. The high-pressure homogenizer that is considered is a GYB40-10S/GY60-6S; with a pre-treatment pressure of $1000 \mathrm{psi}, 2000 \mathrm{psi}$, and $3000 \mathrm{psi}$, the number of passes; 1,2 , and 3, a reaction time of 3, 3.5, and $4 \mathrm{~h}$. Pressure and cavitation increase the efficiency of the pre-treatment process of the homogenizer. In addition, homogenization shear force and pressure are the basic significant factors that enhance the efficiency of microalgae cell rupture. Also, the use of modelling to simulate pre-treatment processes (Response Surface Methodology (RSM), Box-Behnken Designs (BBD), and design of experiment (DOE) for process optimization will be adopted in this study. The results clearly demonstrate that high-pressure homogenization pre-treatment can effectively disrupt microalga cell walls to enhance lipid recovery efficiency, with a relatively short extraction time, both that are essential for maintaining a good quality of lipids for biofuel production. A maximum of $18 \%$ lipid yields were obtained after $3 \mathrm{~h}$ of $\mathrm{HPH}$ pre-treatment at $3000 \mathrm{psi}$.
\end{abstract}

Keywords: high-pressure homogenizer; microalga; cell disruption; lipid extraction; biodiesel; pre-treatment

\section{Introduction}

Presently, more than half of the world's carbon monoxide emissions are seen to be from the automobile industries. Improving this situation seem not to be achieved presently, as it has been reported that there will be an increase of over two-billion automobile vehicles by the $2050[1,2]$. The combustion of fossil fuel produced from the transport sector has many air pollutants that are not environmental friendly. In 2010, it has been predicted that the release of carbon monoxide emission will be over 140 billion metric tonnes by 2035 [3]. In respect to these figures, some countries that depend on the use of fossil fuels as a primary source of energy have the chances of being affected by environmental degradation, which is as a result accumulation of $\mathrm{CO}_{2}$ emissions [3]. The increase in energy demand, and environmental hazards caused by the used of fossil fuels has intensified attention towards the production of clean liquid fuel, termed as biofuels, as an alternative source of energy [4]. Microalga biomass has shown great promise as a sustainable alternative to third generation biofuels as they can potentially produce high rate of triglycerides, etc. The potential feedstock for alga biofuel includes; edible oil (palm oil), non-edible (jatropha) and lignocellulosic biomass (e.g., wood) and microalgae cells $[5,6]$. Production of biofuels does not only reduce the dependence on 
fossil oil trade but also decreases the unavoidable uncertainties caused by the fluctuations in fossil fuel prices. Third generation biofuel seems very interesting for several reasons: it is highly biodegradable and has minimal toxicity, almost zero emission of sulphate, aromatic compounds and other, chemical substances that are destructive to the environment and appears to cause significant improvement of rural economic potentials. The use of microalga for biofuel production requires strain selection, optimisation, and viability testing to ascertain the most appropriate organism for large-scale production. Even as algae biofuels are sustainable, the economic feasibility and large-scale production is still underachieved, simply because of high production the cost and the lack of economic techniques that integrate the multiple steps associated with the harvest, extraction, and conversion process. However, biomass energy will depend on the efficiency of bio-energy refineries as well environmental and technological consideration [7]. Similarly, microalga production process is improving over the past years but has been hindered by some factors during the production process, which has hindered the realisation of its full potential. In some review studies, different pre-treatment techniques have been used for microalga cell rupture, depending on the substrate's morphology to perform a different task, while biofuel production was estimated. Also, many studies have discussed the effect of using homogenous catalyst for biodiesel production, as summarized by [8-26]. Bead mills and high-pressure homogenizer has been designed among the most successful mechanical techniques on microalga biomass to produce biodiesel. Cho et al. [27] used high-pressure homogenizer to extract lipid from Scenedesmus quadricauda, and noted a recovery of $19.8 \%$ of lipid was produced with less temperature and time for extraction. Zheng et al. [28] reported that using a bead milling vessel to extract lipids from Chlorella vulgaris and noted a recovery of $11 \%$, which was lower than the other methods that were tested, while Shen et al. [29] proved that the highest lipid recovery of $18.8 \%$ (C. protothecoides alga biomass) was obtained using bead beater shaking vessel. Similarly, Lee et al. [30] added that bead beating of Botryococcus sp. cells resulted in a lipid extraction of $28 \%$. Other cell pre-treatment using beating includes; Prabakaran and Ravindran, which prove that using microalga cells of (Chlorella sp., Nostoc sp. and Tolypothrix sp.) on a bead beating pre-treatment enhances a lipid recovery of $25-30 \%$. In all of the applications of using mechanical pre-treatment to enhance lipid production, as discussed above, no study has ever given detailed information of how to perform a numerical optimization using pre-treatment process variables to increase lipid production efficiency. From this gap, the aim of this study is to obtain a maximum yield of lipid by optimizing the pre-treatment process parameters using high-pressure homogenizer to improve lipid production efficiency. RSM has been effectively applied in DOE analyses, and been used for mathematical and statistical methods, which are used for modelling and predicting the effect of input process parameters by optimizing their output responses [31], as well as specifying the interaction between responses and their well-regulated input parameters [32]. As most previous studies have observed, the effect of optimizing and modelling process parameters for lipid extraction efficiency is summarised in [33-35].

Microalga cell disintegration is a process of breaking down algae rigid cell wall for an effective lipid production [36,37], where cell rupture is also a process of breaking algae cell [36]. This can be achieved both mechanically, non-mechanically, and as well combined pre-treatment methods [38-41], other techniques include; chemical and physical pre-treatment; e.g., microwave and ultrasonic [42]. According to Ekpemi et al. [34], added that cell disruption is the ability to disintegrate algae cell walls for the release of lipids for industrial uses, where other applications using high-pressure homogenizer are summarized in [43-48]. Also, during microbial cell disruption, viscosity has proven to be an effective parameter to enhance a high degree of cell disintegration [34], while homogenizing microalgae cell, pressure and nozzle diameter, and number of passes still have a significant effect on the disruption rate and enhances lipid production [27]. 


\section{Results and Discussion}

\subsection{Recovered Lipids}

Table 1 indicates an RSM table for design and coded factors for input parameters, where homogenization pressure was at a range of 1000-3000 psi, the number of passes (1-3), and reaction time of (3-4) h. Experimental design are performed using Box-Behnken Design (BDD), when considering the homogenization pressure, number of passes, as well as time of reaction were analyzed, as indicated in Table 2.

Table 1. Response Surface Methodology (RSM) table for design and coded values for input parameter.

\begin{tabular}{ccccc}
\hline Variable & Units & \multicolumn{3}{c}{ Levels } \\
\hline & & -1 & 0 & 1 \\
Pressure & Psi & 1000 & 2000 & 3000 \\
Number of Passes & & 1 & 2 & 3 \\
Extraction Time & $\mathrm{h}$ & 3 & 3.5 & 4 \\
\hline
\end{tabular}

Table 2. Experimental results for both output and input parameters.

\begin{tabular}{cccc}
\hline & Input Factors & & Response \\
\hline Pressure (psi) & Number of Passes & Reaction Time (h) & Recovered Lipids (\%) \\
\hline 3000 & 2 & 3 & 17.693 \\
2000 & 2 & 3.5 & 7.595 \\
2000 & 2 & 3.5 & 7.038 \\
1000 & 2 & 3 & 3.45 \\
2000 & 2 & 3.5 & 7.526 \\
2000 & 2 & 3.5 & 13.937 \\
2000 & 1 & 3 & 5.606 \\
2000 & 2 & 3.5 & 7.202 \\
1000 & 2 & 4 & 3.65 \\
1000 & 1 & 3.5 & 2.744 \\
2000 & 1 & 4 & 8.359 \\
2000 & 3 & 4 & 6.351 \\
3000 & 3 & 3.5 & 10.207 \\
3000 & 2 & 4 & 8.166 \\
2000 & 3 & 3 & 4.496 \\
1000 & 3 & 3.5 & 4.15 \\
3000 & 1 & 3.5 & 16.332 \\
\hline
\end{tabular}

Results of an analysis of variance (ANOVA) from homogenized studies are depicted in Table 3. According to the analysis, all of the variables are statistically significant.

Table 3. Analysis of variance (ANOVA) analysis.

\begin{tabular}{lccccc}
\hline \multicolumn{1}{c}{ Source } & Sum of Squares & df & Mean Square & F Value & $p$-Value prob $>$ F \\
\hline \multicolumn{1}{c}{ Model } & 211.26 & 5 & 42.25 & 4.79 & 0.0143 \\
\hline A-Pressure & 184.36 & 1 & 184.36 & 20.90 & 0.0008 \\
B-Number of passes & 7.68 & 1 & 7.68 & 0.87 & 0.3708 \\
C-Reaction time & 2.78 & 1 & 2.78 & 0.32 & 0.5855 \\
AB & 14.18 & 1 & 14.18 & 1.61 & 0.2310 \\
$\mathrm{~A}^{2}$ & 2.26 & 1 & 2.26 & 0.26 & 0.6223 \\
Residual & 97.01 & 11 & 8.82 & & \\
Lack of Fit & 61.99 & 7 & 8.86 & 1.01 & 0.5280 \\
Pure Error & 35.02 & 4 & 8.76 & & \\
Cor Total & 308.27 & 16 & & & \\
\hline
\end{tabular}

The fit synopsis output outlined, that for output parameters, a sequential model is suggested for more analytical measures containing utmost Pred. and Adj. $R^{2}$ [32]. The ANOVA response surface 
table gives a descriptive idea on the effect of all theinput responses and the significance of the model, where adequacy measures $R^{2}$, adjusted $R^{2}$ and predicted $R^{2}$ have values of $0.6853,0.5423$, and 0.3703 , as indicated in Table 3. In addition, the F-values of 4.79 imply that the model is significant. The "Pred R-Squared" of 0.3703 is in reasonable agreement with the "Adj R-Squared" of 0.5423; i.e., the difference is less than 0.2. The "Lack of Fit F-value" of 1.01 implies that the Lack of Fit is not significant relative to the pure error. There is a $52.80 \%$ chance that a "Lack of Fit F-value" this large could occur due to noise. Also, the adequate precession ratio in the ANOVA response surface linear model is above 4, which specifies that the entire model is very adequate and as a sign good model discrimination. However, for a model to be adequate, the model reduction will certifies and significantly accept the essential statistical analysis to carry out an optimization process [49]. The final equation for the experimental parameters and actual factors, as determined by the software is shown in Equation (1):

$$
\text { Recovered lipids }(\%)=-0.551+5.641 \cdot 10^{-3} \mathrm{P}+2.786 \mathrm{~N}-1.179 \mathrm{R}-1.882 \cdot 10^{-3} \mathrm{PN}+7.312 \cdot 10^{-3} \mathrm{P}^{2}
$$

where:

$\mathrm{P}$ is the pressure

$\mathrm{N}$ is the number of passes

$\mathrm{R}$ is the reaction time

As shown in Table 3, there are three interaction terms that have a significant effect on the amount of lipid produced, which are: pressure, number of passes and reaction time.

Figure 1 represents a perturbation plot that shows the interaction between the three process parameters on the amount of lipid concentration produced. From the plot, the amount lipid concentration produced is because of an increase in homogenization pressure on $\%$ of lipid recovered. This indicates that, as the homogenizing pressure increases, the \% of lipid yield increases; while (b); number of passes show a slightly significant increase in the amount of lipid recovered; (c) Reaction time seem to behave the same way with number passes on the lipid concentration produced. Thus, from the perturbation plot, increase in pressure will constantly improve the amount of lipid produced.
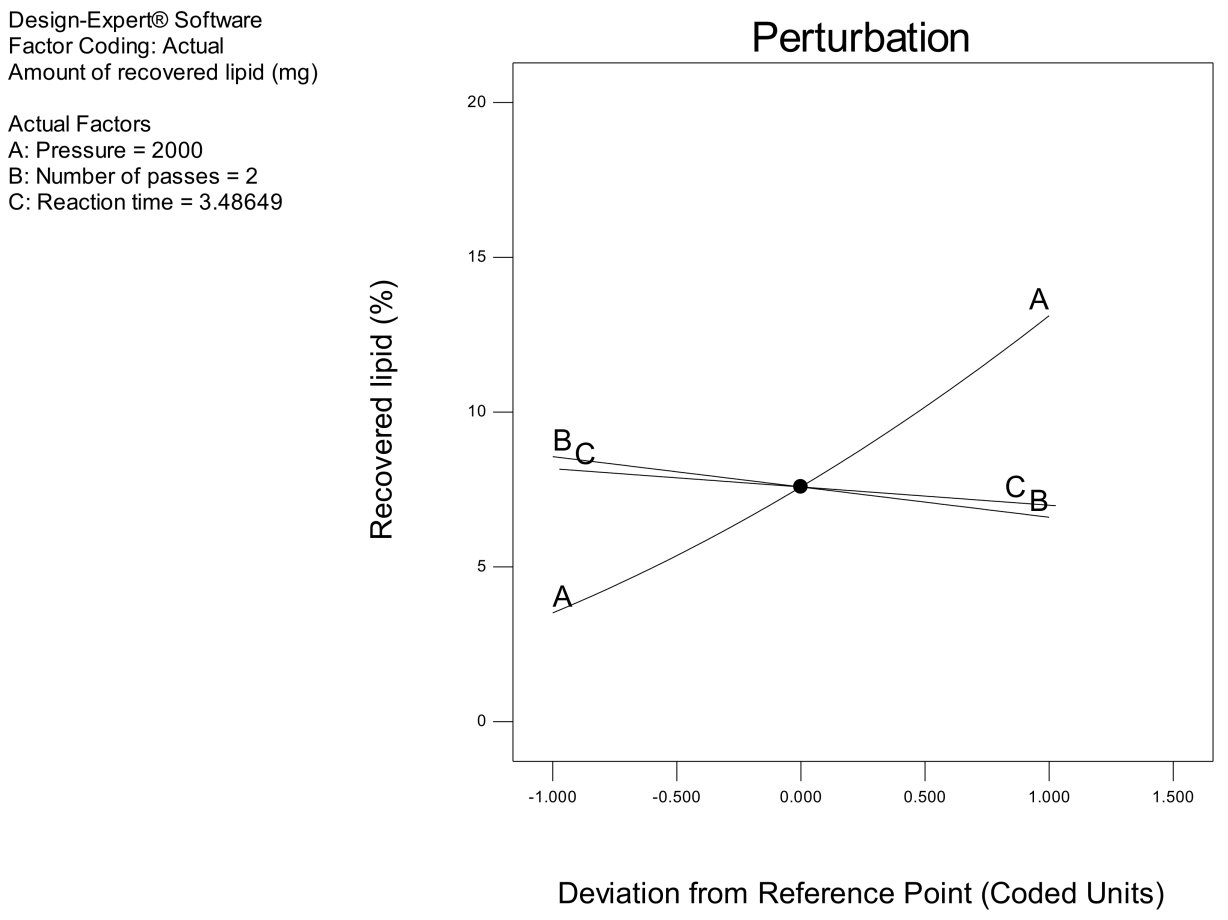

Figure 1. Perturbation plot for percentage of recovered lipids. 
Figure 2 shows a predicted vs. actual plot. This plot shows that our predicted model supports our experimental data, as the square shape figures are seen to be very close to the diagonal line.
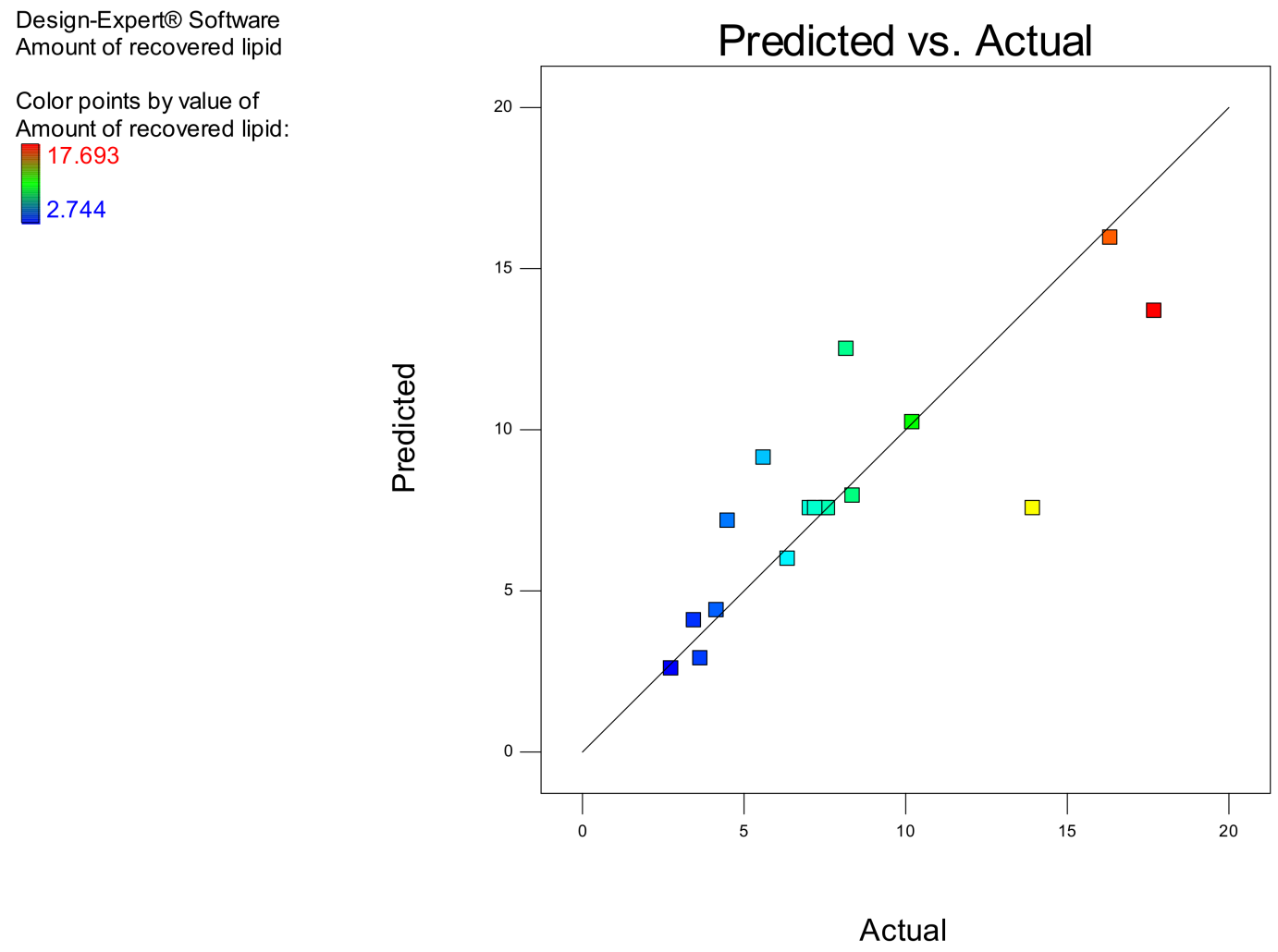

Figure 2. Predicted vs. actual plot.

However, homogenization pressure is shown to be a predominant factor using homogenizer for microalga cell rupture. According to Samarasinghe et al. [50], proved that the most significant parameters for algae cell rupture is a pressure differential across the nozzle and the number of passes through the homogenizer. Also, Yap BHJ et al. [42], discover that the amount of cell rupture will increase with increasing the homogenizing pressure.

\subsection{Response Surface Model (RSM)}

Figures 3 and 4 demonstrate the three-dimensional (3D) plots of the outcome of pressure on $\%$ recovered lipid yield. In Figure 3, at a fixed number of passes 2, and considering a homogenization pressure of $3000 \mathrm{psi}$ and $1000 \mathrm{psi}$ and a reaction time $4 \mathrm{~h}$. The $\%$ of lipid recovered decreases from $15 \%$ to $3 \%$. The final \% of lipid that is recovered at this point is $80 \%$ at $4 \mathrm{~h}$ extraction time. This result confirms that increasing the pressure and the reducing the number of passes does not have any significant effect on lipid extraction efficiency. This may be attributed to the inability of the microalga cell well not completely disrupted during the pre-treatment process to improve lipid extraction efficiency. At a constant homogenization pressure of $3000 \mathrm{psi}$ and considering a reaction time of 3 and $4 \mathrm{~h}$, the percentage of lipid recovered decreases from $15 \%$ to $13 \%$, respectively. The final percentage of lipid yield is $13 \%$. The results confirm that at a pressure of $3000 \mathrm{psi}$ and $3 \mathrm{~h}$ reaction time the final percentage increases to $15 \%$, while at $4 \mathrm{~h}$ extraction time, the lipid yield decreases. This simply proves that at a low reaction time and high pressure the lipid yield efficiency increases, while at higher reaction time and pressure the yield of lipid decreases. In summary, Figure 3, under a high-pressure condition of 3000 psi and number of passes of 3 , satisfy the agreement that a pressure increase results in high yield of lipid produced. 
Design-Expert $\circledast$ Software

Factor Coding: Actual

Amount of recovered lipid (mg)

- Design points above predicted value

- Design points below predicted value

17.693

2.744

$\mathrm{X} 1=\mathrm{A}:$ Pressure

X2 = C: Reaction time

Actual Factor

B: Number of passes $=2$
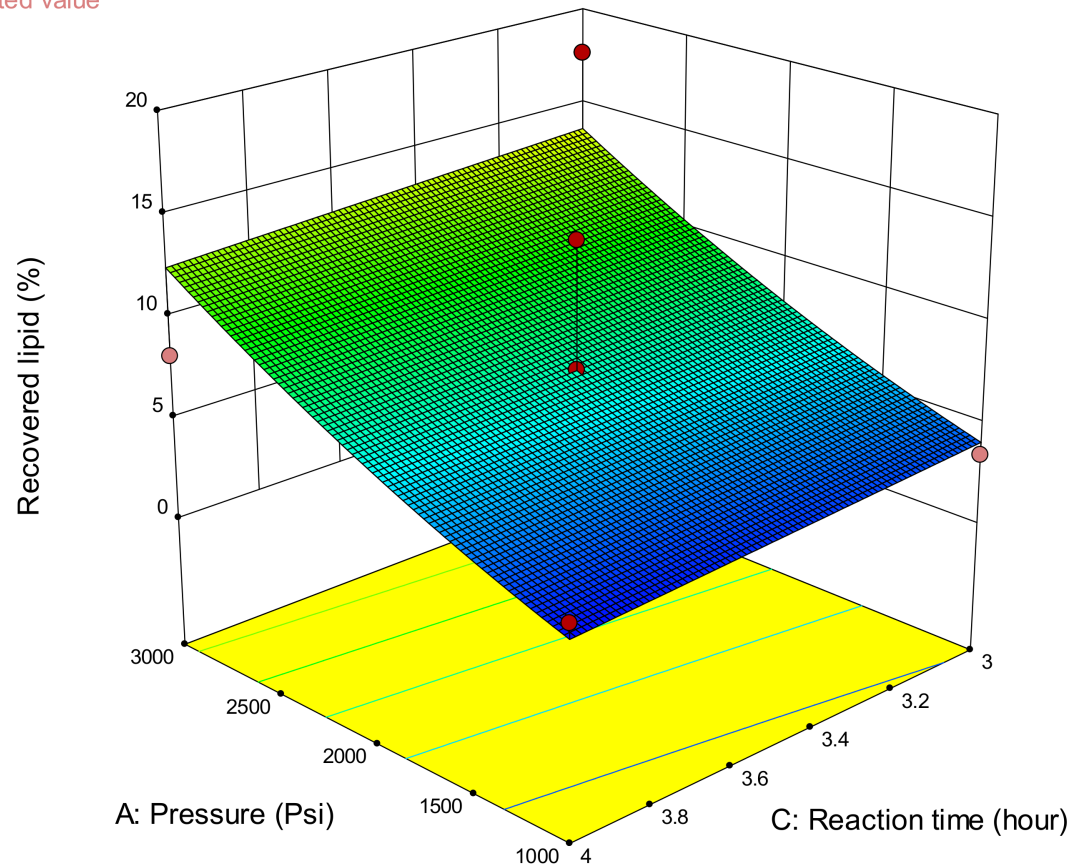

Figure 3. Response surface plot in three-dimensional (3D) for pressure and reaction time for percentage of lipid recovered.

\section{Design-Expert@ Software}

Factor Coding: Actual

Amount of recovered lipid (mg)

17.693

2.744

$\mathrm{X} 1=\mathrm{A}:$ Pressure

$\mathrm{X} 2=\mathrm{B}$ : Number of passes

Actual Factor

C: Reaction time $=3.48649$

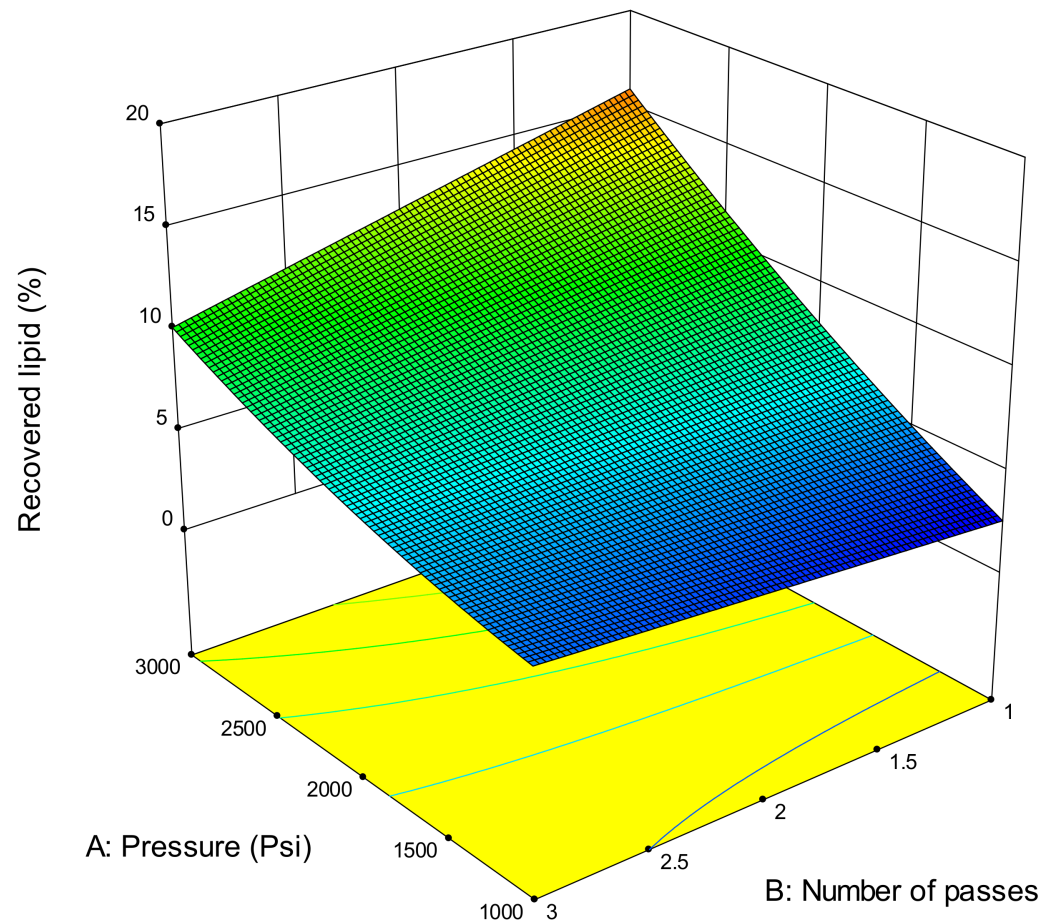

Figure 4. Response surface plot in 3D for Pressure and Number of passes for the percentage of lipid recovered. 
In Figure 4, the plot demonstrates the outcome of homogenization pressure and the passes number on the output response. At a $3.5 \mathrm{~h}$ time of reaction, pressure of 3000 psi and 1000 psi respectively, the $\%$ of lipid yield decreases from $10 \%$ to $4 \%$ respectively. The final percentage yield of lipid is $60 \%$. A decrease in \% yield of lipid may be attributed that during cell pre-treatment at a high the algae cell must have been disrupted completely which made it difficult to extract the lipid even with a high extraction time, while for low pressure and low lipid yield, it might be the algae cells is still intact after completing the pre-treatment even with higher extraction time. For a pressure of $3000 \mathrm{psi}$ and 1000 psi under a fixed reaction time of $3.5 \mathrm{~h}$, the lipid produced was decreased from $16 \%$ and $4 \%$ respectively, while the final \% of lipid produced is $75 \%$. The amount of lipid produced at various pressure difference certifies the idea of [51] that mechanical cell rupture is a process that involves the application pressure differences during homogenization of algae cells. In the literature, previous research work has applied high pressure homogenizer and bead beater for biomass pre-treatment to enhance lipid production efficiency. Cho et al. [27] applied high pressure homogenizer to extract lipid from Scenedesmus quadricauda and recorded a 19.8\% of lipid yield at a pressure of 1200 psi. Zheng et al. [28] observed 11\% lipid yield on Chlorella vulgaris after bead mill pre-treatment. A similar study conducted by Lee et al. [30] achieved a $28 \%$ of lipid yield using Botryococcus sp. after bead mill pre-treatment, while Prabakaran and Ravindran [52] observed that bead beating of (Chlorella sp., Nostoc sp. and Tolypothrix sp.) resulted in 20-30\% lipid yield. The result presented in this present work shows a maximum lipid yield of $18 \%$ achieved at $3 \mathrm{~h}$ of $\mathrm{HPH}$ at $3000 \mathrm{psi}$. The result agreed with Ekpeni et al. [34] who observed that increase in pressure increases the highest protein concentration. While Lee et al. [53] proved that increasing pressure during microalgae cell pre-treatment using HPH increases cell disruption efficient to enhance lipid production. Halim et al. [54] noted 90\% disruption efficiency by increasing the HPH operating pressure. Conclusively, shear stresses influences pressure, and it is dependent of relative velocity which enhances a high degree of cell disruption efficiency of algae biomass [55]. The two 3D response surface plots indicate that pressure increases after homogenization significantly increases the amount of recovered lipid after extraction.

As previously emphasized in perturbation plot, Figure 1; show that homogenization pressure and passes number have a significant outcome on homogenized algae cell. Both of the parameters (homogenization pressure and passes number) have a positive impact on homogenized algae cell disruption. As the homogenization passes number comes into effect, the microalgae cells are being disrupted after each phase or passes on the homogenizer. After the one to three passes, it is assumed that the thick algae cells have been disrupted to enhance an efficient lipid production. The effect of reaction time on lipid production as being studied in this work shows that the highest amount of lipid yield is obtained in $4 \mathrm{~h}$. This indicates that increasing the reaction time, as shown in Table 3, does not have a much significant difference in output responses. Past studies have reported that decreasing reaction time increases the amount of biodiesel yield and production cost [56-69]. This scenario shows that even as the time of reaction is increases, there was no significant outcome on the $\%$ of lipid recovered.

\subsection{Optimization of Lipid Recovered}

From the response surface mathematical model, as indicated in Equation (1), that defines the significant effects of input variables on the output responses (\% of lipid recovered), a study on optimization were performed using Design Expert Software V10. While the basic reason for conducting the optimization is to combine the productivity and cost of the entire process. The percentage of lipid produced was maximized with level 5, and the number of passes was maximized at level 5 , the homogenizing pressure varies in the ranges specified in Table 1. The optimal recovered lipid yield of 16.55 from the numerical optimization was achieved at a number of passes $=1$, pressure $=$ $3000 \mathrm{psi}$, and reaction time $=3 \mathrm{~h}$. The graphical optimization plots (Figures 5 and 6 ) clearly shows the optimal input responses (optimal parameters by means visual observation. The yellow region in the graphical optimization plot indicates that the ideal values certify that the calculated standard as indicated in the curve agrees with the standard of optimization criteria. The plots clearly established 
that the optimum conditions for a maximized \% of recovered lipids are at a pressure of $3000 \mathrm{psi}$, the number of passes $=1$, and reaction time of $3 \mathrm{~h}$ of high-pressure homogenizer pre-treatment.
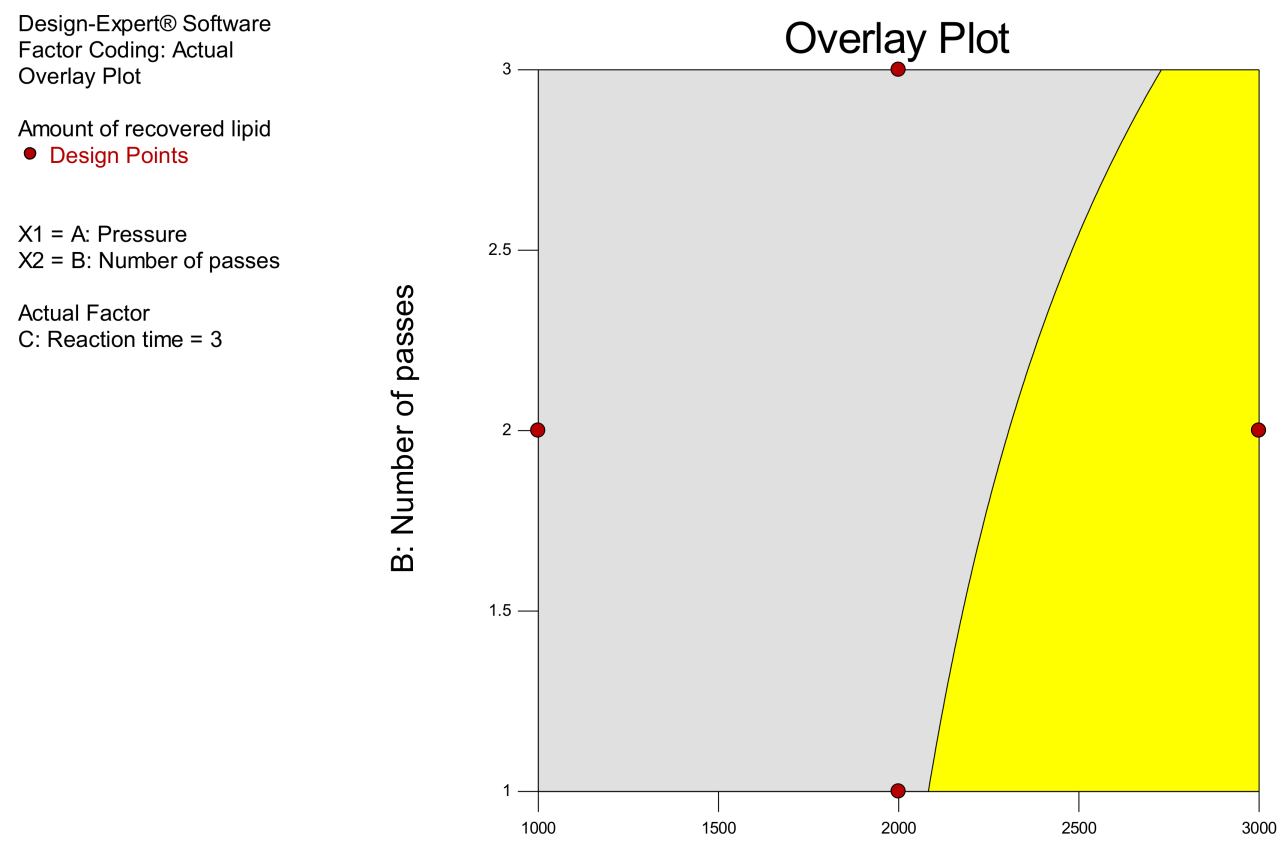

A: Pressure (Psi)

Figure 5. Graphical optimization for maximizing the percentage of recovered lipid yield minimizing pressure.
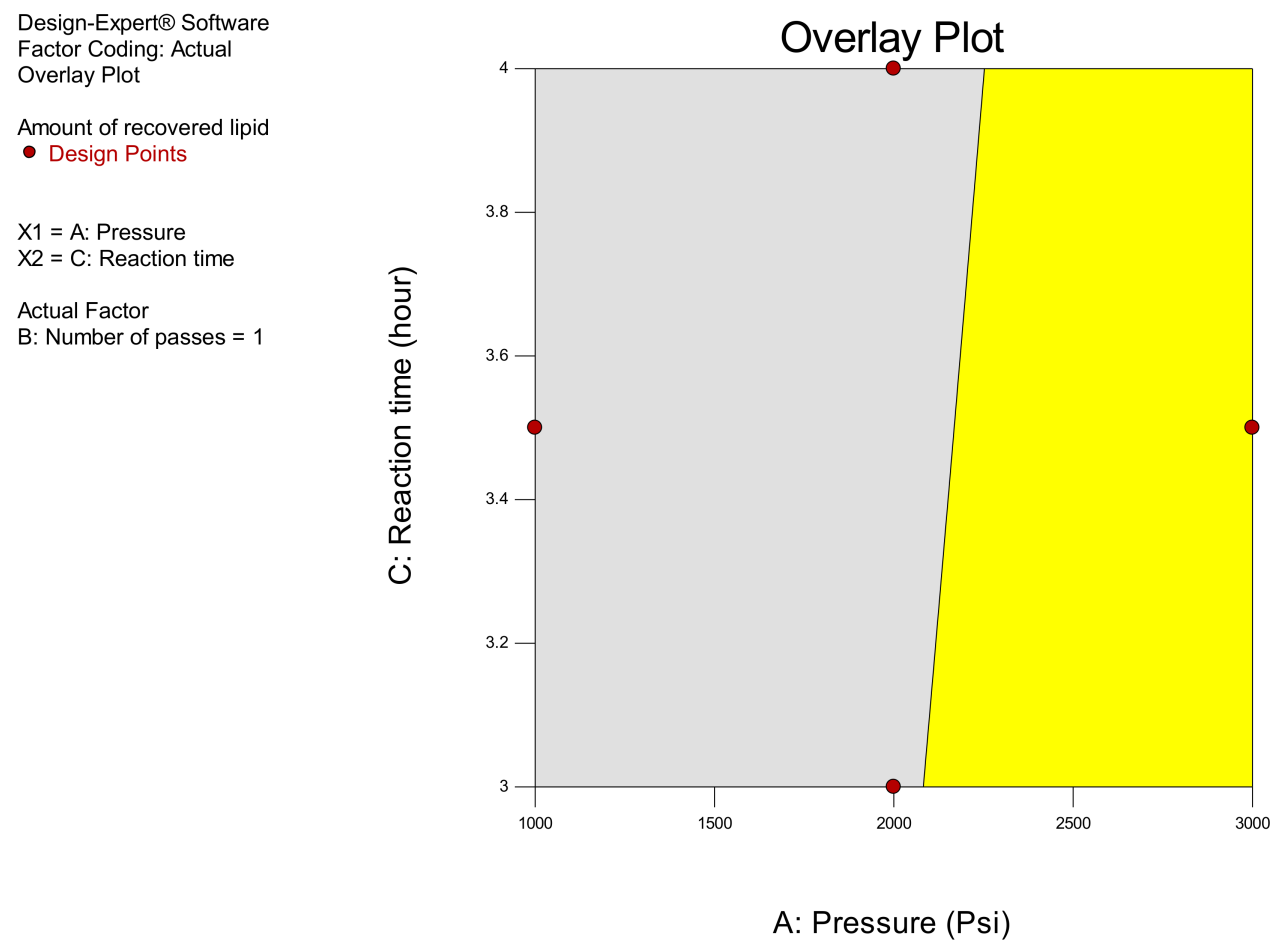

Figure 6. Graphical optimization for maximizing percentage of recovered lipid yield and minimizing the pressure. 


\section{Materials and Methods}

Cultivation of Microalgae: In this study microalgae strain, namely; A290 Scenedesmus quadricauda purchased from Sciento, 61 Bury Old Road Whitefield MANCHESTER M45 6TB United Kingdom. The strain was explored in terms of growth under room temperature and was stored in a freezer at a temperature of 0 to $4{ }^{\circ} \mathrm{C}$ for one week.

\subsection{Medium and Culture Conditions}

Four conical flasks of five-liter sizes were thoroughly washed and allowed to dry at room temperature by placing them inversely on the laboratory rack as shown in Figure 7. The dried flask was then sterilized at $60^{\circ} \mathrm{C}$ for $4 \mathrm{~h}$, and then allowed to cool before using. Exactly four liters of distilled water $\mathrm{H}_{2} \mathrm{O}$ was poured in each sterilized flask following the inoculation of $0.4 \mathrm{~g}$ of the microalga into the flask, which $1.5 \mathrm{~g}$ of K10 (Unicellular algae medium) (chemical composition includes; Sodium nitrate, Magnesium sulphate, Dipotassium hydrogen orthophosphate, Calcium chloride, Ammonium chloride and Trace elements with weight (\%) of $62,16,15,4,3$, and $<1$, respectively) were added to each flask. After the additions, the flasks were vigorously shaken to ensure proper circulation of the nutrients inside the flasks. The pumps that supply air $\left(\mathrm{CO}_{2}\right)$ were then directly connected maintained for an effective growth. A 24-h white fluorescent light intensity of 75 lumens was maintained during the culture period. At $6 \mathrm{~h}$ interval, each of the flasks was jiggled (hand shake manually) to avoid the settling of the nutrients at the bottom of the flask. The microalga sample were cultured for a period of 14 days (two weeks).

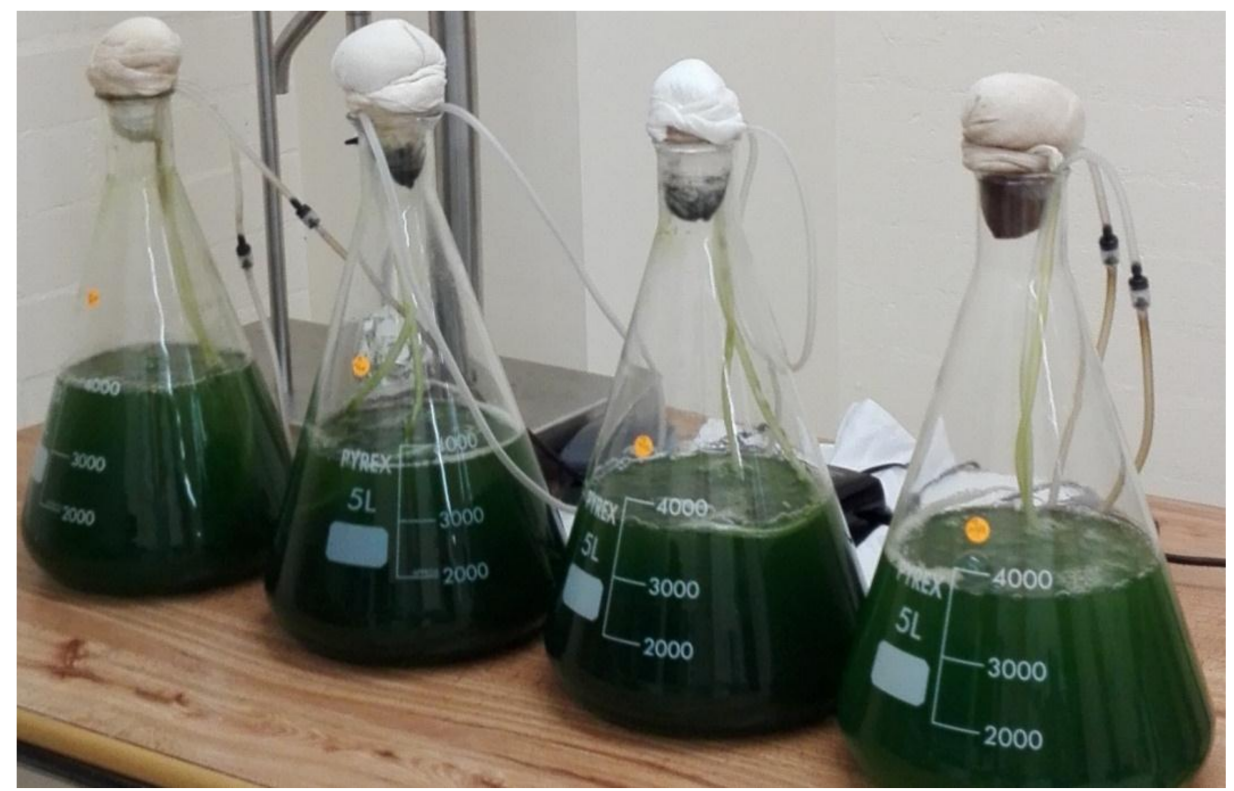

Figure 7. Microalga culture.

\subsection{Determination of Specific Growth Rate of the Microalga and Cell Concentration}

Specific Growth Rate is a measure of the number of generations (the number of doublings) that occur per unit of time in an exponentially growing culture [70]. Hence, it was obtained using the equation below:

$$
\mu=\ln \frac{N_{t}}{N_{o}}=T_{t}-T_{0}
$$

where;

$N_{t}$ is the number of cell at the end of log phase 
$N_{o}$ is the number of cells at the start of log phase

$T_{t}$ is the final day of log phase

$T_{0}$ is the initial day of log phase

The initial concentration of the Scenedesmus quadricauda cells is $=1.815 \times 10^{9} \mathrm{~g} / \mathrm{mL}$ (Inoculum). While the final concentration after day two was $3.975 \times 10^{8} \mathrm{~g} / \mathrm{mL}$.

\subsection{Microalga Cell Pre-Treatment}

The machine in Figure 8 is comprises of two homogenizing valves and single pump. The two valves (homogenizing) pressure are used to control and to maintain a steady pressure before cell pre-treatment. Before homogenization of cultured microalgae samples, run clean water $\left(\mathrm{H}_{2} \mathrm{O}\right)$ through the inlet nozzle, and switch on the machine to clean up the entire homogenizing chambers. Use the first homogenizing valve to set up the required pressure and the second valve to maintain a steady pressure during microalgae cell disruption. $500 \mathrm{~mL}$ flask of cultured samples (microalga) were poured through the inlet nozzle and homogenized at a variable pressure of 3000 psi, 2000 psi, 1000 psi, number of passes of 1,2, and 3, respectively. Where Figure 8 (right), indicates how algae cells are being disrupted with the effects the homogenization components (valve head and seat, impact ring). The laboratory work was performed with GYB40-10S/GY60-6S high-pressure homogenizer (Source: No, 188 DouHui Road, MiniHang Area, Shanghai china. Email: donghua@donghuamachine.com).
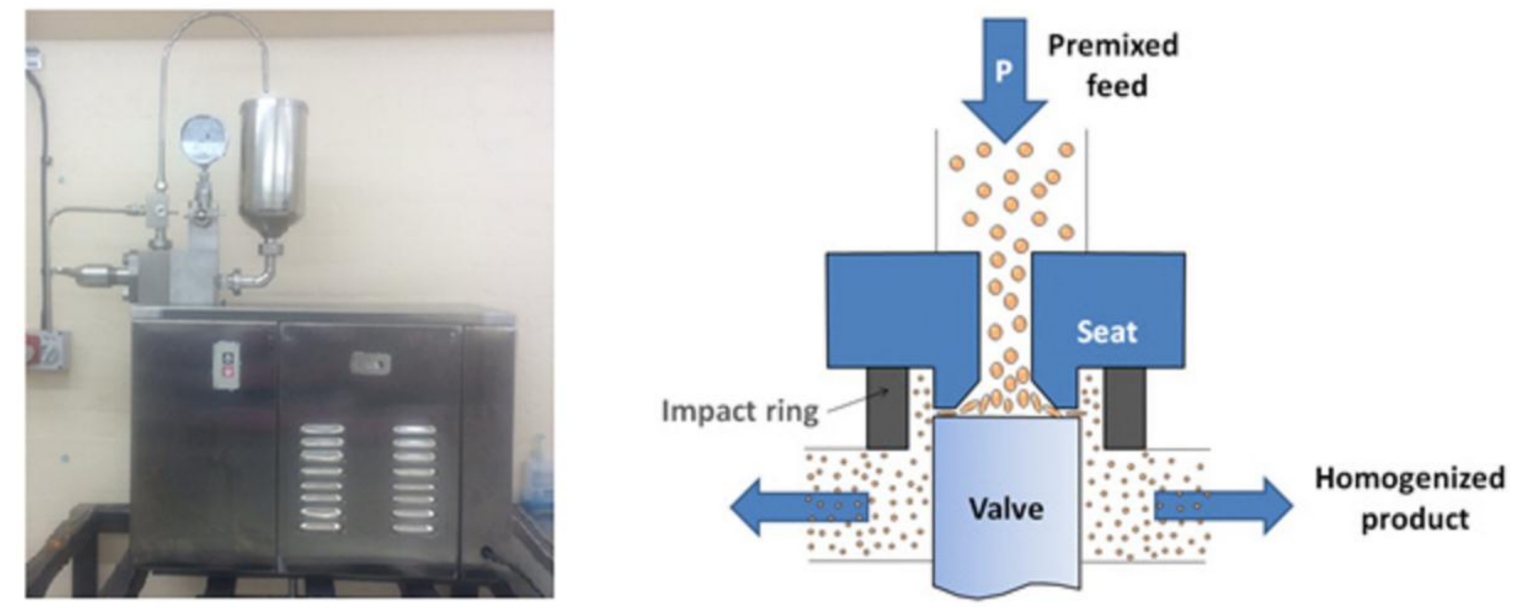

Figure 8. High-Pressure Homogenizer (HPH) used in this study (left), Operational performance of high-pressure homogenizer (right).

\subsection{Extraction Procedure}

A $500 \mathrm{~cm}^{3}$ of each homogenized sample was placed in a round bottom flask containing $500 \mathrm{~cm}^{3}$ of methanol as an organic solvent were mixed with $10 \mathrm{~cm}^{3}$ of concentrated sulphuric acid and inserted into a round bottom flask. Methanol as an organic solvent has been previously used by many studies for effective lipid extraction because of low cost and easy extraction time. Then, anti-bump granules were added to the round bottom flask and a condenser fitted inside the flask before reflux. The homogenized microalga samples were poured into the round bottom and reflux according to the selected reflux time for $3,3.5$, and $4 \mathrm{~h}$, respectively using a heating mantle. After cooling for two to three hours, the mixture was poured into a separating funnel for extraction. The FAME mixture was then extracted using $3 \times 150 \mathrm{~cm}^{3}$ and one portion of diethyl ether and washed with $5 \%$ of sodium bicarbonate solution. The solution was then tested to ensure that it was neutral using a $\mathrm{pH}$ paper to avoid any trace of acid inside the extract. The lipid extract was poured into a tiny beaker and was placed in a steam bath at a temperature less than $30^{\circ} \mathrm{C}$ for 3 mins to remove some tiny solvents contained in the lipid produced. 


\subsection{Gas Chromatography}

The lipid extract was examined by gas chromatography (AGILENT GC 78ZOA), with a Flame Ionization Detector (FID), an automatic sample injector, gas chromatography injectors and detectors, and capillary column of diameter $0.2-0.7 \mathrm{~mm}, 100 \mathrm{~m}$ long, flow rate of $0.5-15 \mathrm{~mL} / \mathrm{min}$, head pressure of 3-40 psi, capacity of $100 \mathrm{mg} /$ pack, film thickness of $0.1-8 \mu \mathrm{m}$. The packed column has a length of $0.5-5 \mathrm{~m}$, a diameter of $2-4 \mathrm{~mm}$, flow rate $10-60 \mathrm{~mL} / \mathrm{min}$, the head pressure of $10-40 \mathrm{psi}$, a capacity of $10 \mu \mathrm{g} / \mathrm{pack}$, and the film thickness of 1-10 $\mu \mathrm{m}$. Helium, hydrogen, and nitrogen are being used as a carrier gas, while diethyl ether serves as a solvent during the analysis. During GC analysis, 37 components certified standard of FAME's was used to confirm the presence of the individual FAME and to accurately calculate the concentration of the components found. A second sample was used, which was a standard 80:20 mixture of biodiesel and diesel from a soya source. Each sample was injected at a volume of $1 \mu \mathrm{L}$ and the resulting chromatograms were used to identify each of the FAME's by their retention times using the standard. Once identified, the concentrations were calculated by using the peak area. This allowed for the concentrations to be calculated in $\mu \mathrm{g} / \mathrm{ml}(\mathrm{ppb})$ and as a percentage of the total peak area.

To understand the true yield of FAMEs, the crude biodiesel samples were analyzed by GC. The fatty acid methyl ester in biodiesel mix was assessed by a comparison of fatty acid methyl esters peak area, biodiesel standard, biodiesel mix, and their retention time. However, the basic fatty acid or analytes found includes; methyl myristate $-\mathrm{C} 14$, methyl palmitate $-\mathrm{C} 16$, methyl stearate $-\mathrm{C} 18$, methyl linoleate $-\mathrm{C} 18: 2$, methyl arachidate $-\mathrm{C} 20$, methyl eicosate $-\mathrm{C} 20: 1$, methyl eicosadienoate $-\mathrm{C} 20: 2$, and methyl erucate-C22. The analyses found indicate that biodiesel samples contain a high proportion of monounsaturated FAMEs, while the lipid extract contains a high concentration of Methyl myristate-C14 and Methyl palmitate-C16 at a value of 154.73 and 268.12, respectively, as shown in Figure 9. The analyses found fully fit well with the basic requirements of biodiesel mix from soya feedstock and fame standard.

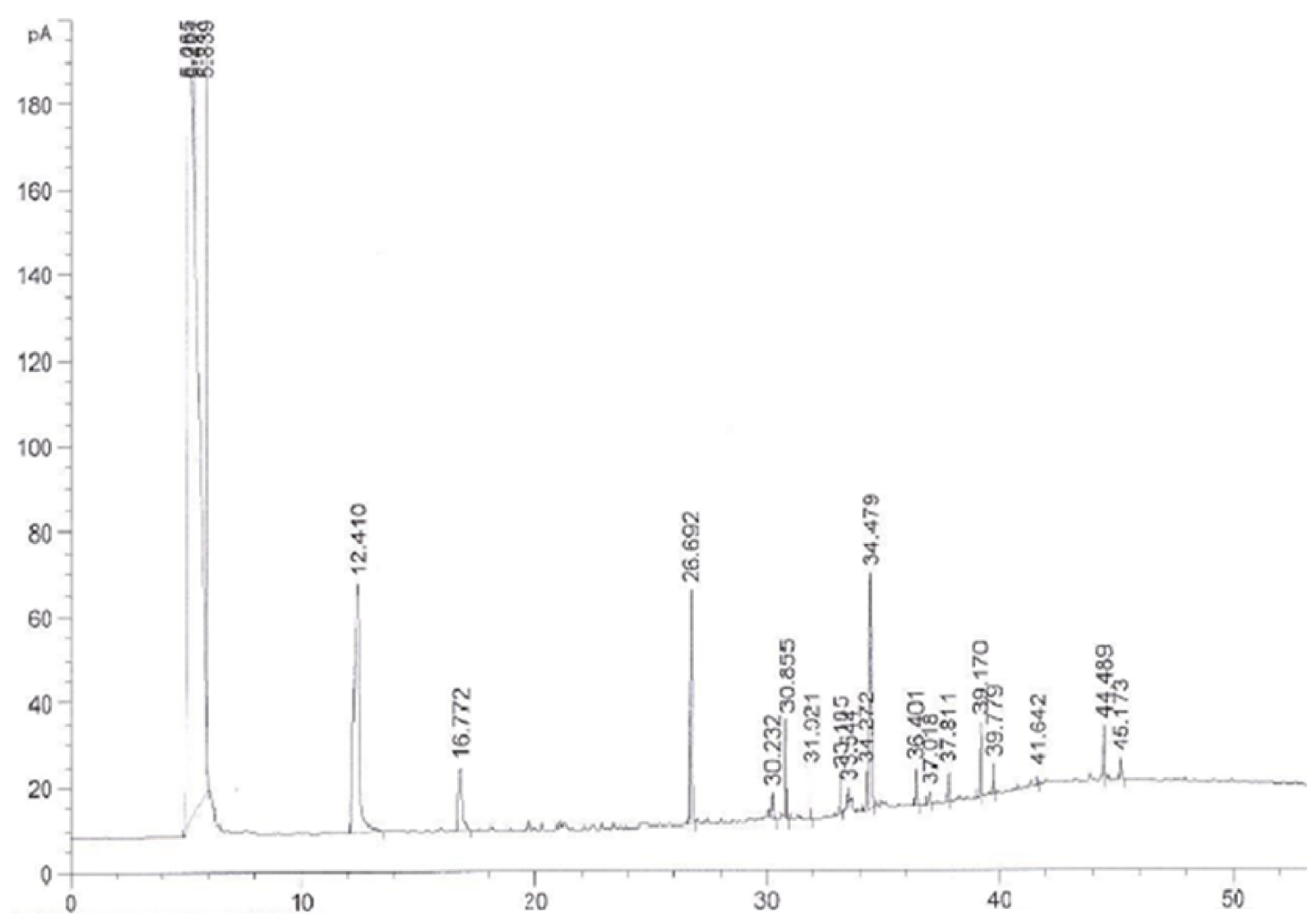

Figure 9. Gas chromatography-mass spectrometry (GC-MS) of Scenedesmus quadricauda lipid extraction. 


\subsection{Experimental Design}

In this paper, a design of experiment will be adopted to analyze the effect of input responses, as well as to test the efficiency of each of the input responses to the output response (\% of lipid produced), where $\%$ of lipid produced is the amount of lipid extracted divided by the dry weight of alga biomass in each 500-mL flask used for each pre-treatment. Design of experiment application has been extensively used in most of engineering data solving techniques [71]. This method (DOE) has been used to determine experimental design order, performing statistical analysis, and showcase a graphical representation of the effects on input parameters to output responses. However, DOE has been applied in different areas as summarized by $[72,73]$.

\subsection{Response Surface Methodology (RSM)}

This approach is an effective statistical technique for modeling, interpreting outputs of interest of single or multiple responses. Similarly, response surface methods consist of the experimental strategy for exploring the space of the processor input factors, empirical statistical modeling to develop an appropriate approximating relationship between the yield and the process variables, and optimization methods for finding the levels or values of the process variables that produce the desirable values of the response outputs. The initial step for RSM is to determine the limits of the experimental domain to be explored; these limits are selected to give a distinct response from the model. The homogenizing pressure, number of passes, and reaction time are the input variables selected for this study, as shown in Table 2. The next step is how the experiment will be designed by RSM using Box-Behnken Design.

\subsection{Box-Behnken Designs (BBD)}

Box-Behnken Design as applied in this study is design from values: $-1,0$ and +1 , as indicated in Table 1. It is formed by a combination of two different stages with unfinished block scheme, it generates designs with required arithmetical steps, by a fraction of the experimental requirements for three-level factorial [34]. Base on three level factorials, the quadratic model is suitable, while blocking selection is presented for all of the schemes that are used [73]. This shows that Response surface methodology as defined above is used for explicating and estimating all experimental process parameters X (level- $j$ ). This aim is to perform optimization criteria for both single and numerous responses $\left(\mathrm{y}^{\prime}\right)$, in this research work, the output response (single response) is the percentage of lipid recovered, as specifically indicated in Equation (3).

$$
\mathrm{Y}=\mathrm{b}_{0}+\sum \mathrm{b}_{\mathrm{i}} \mathrm{X}_{\mathrm{i}}+\sum \mathrm{b}_{\mathrm{ii}} \mathrm{X}_{\mathrm{ii}}+\sum \mathrm{b}_{\mathrm{ij}} \mathrm{X}_{\mathrm{i}} \mathrm{X}_{\mathrm{j}}
$$

\section{Conclusions}

The wet biomass pre-treatment in this research study has proved to enhance the effective lipid yield of $49 \%$ from wet Scenedesmus quadricauda sp. using methanol and sulfuric acid during the extraction process. This substantial development of the effective conversion process (\% of lipid recovered) is highly promising, as this can reduce the large amount of energy consumed during drying process before extraction. The optimal conditions for lipid yields were at a pressure $3000 \mathrm{psi}$, number of passes of 2 and reaction time of $3 \mathrm{~h}$. This method can be very useful to increase the efficiency of producing microalga lipid yield for biodiesel production as an alternative renewable resource to reduce the global effect of fossil fuels. Conclusively, this has been proved a successful conversion analysis of lipid extract and clearly shows that producing biofuel from microalga biomass after optimizing the pre-treatment process is potentially feasible".

Author Contributions: Chukwuma Onumaegbu, Abed Alaswad and Abdul G. Olabi conceived and designed the experiments; Chukwuma Onumaegbu, Abed Alaswad performs the experiments; Chukwuma Onumaegbu, Abed Alaswad and Cristina Rodriguez analyzed the data; Chukwuma Onumaegbu wrote the paper.

Conflicts of Interest: The authors declare no conflict of interest. 


\section{References}

1. Balat, M.; Balat, H. Progress in biodiesel processing. Appl. Energy 2010, 87, 1815-1835. [CrossRef]

2. Wilberforce, T.; El-Hassan, Z.; Khatib, F.N.; Al Makky, A.; Baroutaji, A.; Carton, J.G.; Olabi, A.G. Developments of electric cars and fuel cell hydrogen electric cars. Int. J. Hydrog. Energy 2017, 42, 25695-25734. [CrossRef]

3. Atabani, A.E.; Silitonga, A.S.; Badruddin, I.A.; Mahlia, T.M.I.; Masjuki, H.H.; Mekhilef, S. A comprehensive review on biodiesel as an alternative energy resource and its characteristics. Renew. Sustain. Energy Rev. 2012, 16, 2070-2093. [CrossRef]

4. Wilberforce, T.; El-Hassan, Z.; Khatib, F.N.; Al Makky, A.; Mooney, J.; Barouaji, A.; Carton, J.G.; Olabi, A.G. Development of Bi-polar plate design of PEM fuel cell using CFD techniques. Int. J. Hydrog. Energy 2017, 42, 25663-25685. [CrossRef]

5. Rodriguez, C.; Alaswad, A.; Benyounis, K.Y.; Olabi, A.G. Pretreatment techniques used in biogas production from grass. Renew. Sustain. Energy Rev. 2017, 68, 1193-1204. [CrossRef]

6. Rodriguez, C.; Alaswad, A.; Mooney, J.; Prescott, T.; Olabi, A.G. Pre-treatment techniques used for anaerobic digestion of algae. Fuel Process. Technol. 2015, 138, 765-779. [CrossRef]

7. Gokcol, C.; Dursun, B.; Alboyaci, B.; Sunan, E. Importance of biomass energy as alternative to other sources in Turkey. Energy Policy 2009, 37, 424-431. [CrossRef]

8. Surendhiran, D.; Vijay, M. Microalgal Biodiesel-A Comprehensive Review on the Potential and Alternative Biofuel. J. Chem. Sci. 2012, 2, 71-82.

9. Macías-Sánchez, M.D.; Robles-Medina, A.; Hita-Peña, E.; Jiménez-Callejón, M.J.; Estéban-Cerdán, L.; González-Moreno, P.A.; Molina-Grima, E. Biodiesel production from wet microalgal biomass by direct transesterification. Fuel 2015, 150, 14-20. [CrossRef]

10. Taher, H.; Al-Zuhair, S.; Al-Marzouqi, A.H.; Haik, Y.; Farid, M.M. A Review of Enzymatic Transesterification of Microalgal Oil-Based Biodiesel Using Supercritical Technology. Enzym. Res. 2011, 2011, 1-25. [CrossRef] [PubMed]

11. Dai, Y.M.; Wu, J.S.; Chen, C.C.; Chen, K.T. Evaluating the optimum operating parameters on transesterification reaction for biodiesel production over a $\mathrm{LiAlO}_{2}$ catalyst. Chem. Eng. J. 2015, 280, 370-376. [CrossRef]

12. Shankar, V.; Jambulingam, R. Waste crab shell derived CaO impregnated Na-ZSM-5 as a solid base catalyst for the transesterification of neem oil into biodiesel. Sustain. Environ. Res. 2017, 27, 273-278. [CrossRef]

13. Galadima, A.; Muraza, O. Biodiesel production from algae by using heterogeneous catalysts: A critical review. Energy 2014, 78, 72-83. [CrossRef]

14. Mittelbach, M. Advances in Biodiesel Production; Elsevier: Amsterdam, The Netherlands, 2012. [CrossRef]

15. Bhangu, S.K.; Gupta, S.; Ashokkumar, M. Ultrasonic enhancement of lipase-catalysed transesterification for biodiesel synthesis. Ultrason. Sonochem. 2017, 34, 305-309. [CrossRef] [PubMed]

16. Colombo, K.; Ender, L.; Barros, A.A.C. The study of biodiesel production using $\mathrm{CaO}$ as a heterogeneous catalytic reaction. Egypt. J. Pet. 2017, 26, 341-349. [CrossRef]

17. Amini, Z.; Ilham, Z.; Ong, H.C.; Mazaheri, H.; Chen, W.H. State of the art and prospective of lipase-catalyzed transesterification reaction for biodiesel production. Energy Convers. Manag. 2017, 141, 339-453. [CrossRef]

18. Balasubramanian, R.; Sircar, A.; Sivakumar, P.; Anbarasu, K. Production of biodiesel from dairy wastewater sludge: A laboratory and pilot scale study. Egypt. J. Pet. 2018. [CrossRef]

19. Lin, J.J.; Chen, Y.W. Production of biodiesel by transesterification of Jatropha oil with microwave heating. J. Taiwan Inst. Chem. Eng. 2017, 75, 43-50. [CrossRef]

20. Zeng, D.; Yang, L.; Fang, T. Process optimization, kinetic and thermodynamic studies on biodiesel production by supercritical methanol transesterification with $\mathrm{CH}_{3} \mathrm{ONa}$ catalyst. Fuel 2017, 203, 739-748. [CrossRef]

21. Ding, H.; Ye, W.; Wang, Y.; Wang, X.; Li, L.; Liu, D.; Gui, J.; Song, C.; Ji, N. Process intensification of transesterification for biodiesel production from palm oil: Microwave irradiation on transesterification reaction catalyzed by acidic imidazolium ionic liquids. Energy 2018, 144, 957-967. [CrossRef]

22. Ghosh, S.; Banerjee, S.; Das, D. Process intensification of biodiesel production from Chlorella sp. MJ 11/11 by single step transesterification. Algal Res. 2017, 27, 12-20. [CrossRef] 
23. Milano, J.; Ong, H.C.; Masjuki, H.H.; Silitonga, A.S.; Chen, W.H.; Kusumo, F.; Dharma, S.; Sebayang, A.H. Optimization of biodiesel production by microwave irradiation-assisted transesterification for waste cooking oil-Calophyllum inophyllum oil via response surface methodology. Energy Convers. Manag. 2018, 158, 400-415. [CrossRef]

24. Narula, V.; Khan, M.F.; Negi, A.; Kalra, S.; Thakur, A.; Jain, S. Low temperature optimization of biodiesel production from algal oil using $\mathrm{CaO}$ and $\mathrm{CaO} / \mathrm{Al}_{2} \mathrm{O}_{3}$ as catalyst by the application of response surface methodology. Energy 2017, 140, 879-884. [CrossRef]

25. Nguyen, H.C.; Liang, S.H.; Li, S.Y.; Su, C.H.; Chien, C.C.; Chen, Y.J.; Huong, D.T.M. Direct transesterification of black soldier fly larvae (Hermetia illucens) for biodiesel production. J. Taiwan Inst. Chem. Eng. 2018, 85, 165-169. [CrossRef]

26. Baskar, G.; Aberna Ebenezer Selvakumari, I.; Aiswarya, R. Biodiesel production from castor oil using heterogeneous Ni doped ZnO nanocatalyst. Bioresour. Technol. 2018, 250, 793-798. [CrossRef] [PubMed]

27. Cho, S.-C.; Choi, W.-Y.; Oh, S.-H.; Lee, C.-G.; Seo, Y.-C.; Kim, J.-S.; Song, C.-H.; Kim, G.-V.; Lee, S.-Y.; Kang, D.-H.; et al. Enhancement of lipid extraction from marine microalga, Scenedesmus associated with high-pressure homogenization process. J. Biomed. Biotechnol. 2012, 2012, 359432. [CrossRef] [PubMed]

28. Zheng, H.; Yin, J.; Gao, Z.; Huang, H.; Ji, X.; Dou, C. Disruption of Chlorella vulgaris cells for the release of biodiesel-producing lipids: A comparison of grinding, ultrasonication, bead milling, enzymatic lysis, and microwaves. Appl. Biochem. Biotechnol. 2011, 164, 1215-1224. [CrossRef] [PubMed]

29. Shen, Y.; Pei, Z.; Yuan, W.; Mao, E. Effect of nitrogen and extraction method on algae lipid yield. Int. J. Agric. Biol. Eng. 2009, 2, 51-57. [CrossRef]

30. Lee, J.Y.; Yoo, C.; Jun, S.Y.; Ahn, C.Y.; Oh, H.M. Comparison of several methods for effective lipid extraction from microalgae. Bioresour. Technol. 2010, 101, S75-S77. [CrossRef] [PubMed]

31. Olabi, A.G. Materials \& Design Minimisation of the residual stress in the heat affected zone by means of numerical methods. Mater. Des. 2007, 28, 2295-2302. [CrossRef]

32. Benyounis, K.Y.; Olabi, A.G.; Hashmi, M.S.J. Multi-response optimization of $\mathrm{CO}_{2}$ laser-welding process of austenitic stainless steel. Opt. Laser Technol. 2008, 40, 76-87. [CrossRef]

33. Halim, R.; Rupasinghe, T.W.T.; Tull, D.L.; Webley, P.A. Modelling the kinetics of lipid extraction from wet microalgal concentrate: A novel perspective on a classical process. Chem. Eng. J. 2014, 242, 234-253. [CrossRef]

34. Ekpeni, L.E.N.; Benyounis, K.Y.; Nkem-Ekpeni, F.F.; Stokes, J.; Olabi, A.G. Underlying factors to consider in improving energy yield from biomass source through yeast use on high-pressure homogenizer (hph). Energy 2015, 81, 74-83. [CrossRef]

35. Ekpeni, L.E.N.; Nkem-Ekpeni, F.F.; Benyounis, K.Y.; Aboderheeba, A.K.M.; Stokes, J.; Olabi, A.G. Yeast: A Potential Biomass Substrate for the Production of Cleaner Energy (Biogas). Energy Procedia 2014, 61, 1718-1731. [CrossRef]

36. Spiden, E.M.; Scales, P.J.; Kentish, S.E.; Martin, G.J.O. Critical analysis of quantitative indicators of cell disruption applied to Saccharomyces cerevisiae processed with an industrial high pressure homogenizer. Biochem. Eng. J. 2013, 70, 120-126. [CrossRef]

37. Guldhe, A.; Singh, B.; Rawat, I.; Ramluckan, K.; Bux, F. Efficacy of drying and cell disruption techniques on lipid recovery from microalgae for biodiesel production. Fuel 2014, 128, 46-52. [CrossRef]

38. Miranda, J.R.; Passarinho, P.C.; Gouveia, L. Pre-treatment optimization of Scenedesmus obliquus microalga for bioethanol production. Bioresour. Technol. 2012, 104, 342-348. [CrossRef] [PubMed]

39. Wang, M.; Yuan, W.; Jiang, X.; Jing, Y.; Wang, Z. Disruption of microalgal cells using high-frequency focused ultrasound. Bioresour. Technol. 2014, 153, 315-321. [CrossRef] [PubMed]

40. Grimi, N.; Dubois, A.; Marchal, L.; Jubeau, S.; Lebovka, N.I.; Vorobiev, E. Selective extraction from microalgae Nannochloropsis sp. using different methods of cell disruption. Bioresour. Technol. 2014, 153, 254-259. [CrossRef] [PubMed]

41. Show, K.Y.; Lee, D.J.; Tay, J.H.; Lee, T.M.; Chang, J.S. Microalgal drying and cell disruption-Recent advances. Bioresour. Technol. 2015, 184, 258-266. [CrossRef] [PubMed]

42. Yap, B.H.J.; Crawford, S.A.; Dumsday, G.J.; Scales, P.J.; Martin, G.J.O. A mechanistic study of algal cell disruption and its effect on lipid recovery by solvent extraction. Algal Res. 2014, 5, 112-120. [CrossRef] 
43. Cruz, N.S.; Capellas, M.; Jaramillo, D.P.; Trujillo, A.J.; Guamis, B.; Ferragut, V. Soymilk treated by ultra high-pressure homogenization: Acid coagulation properties and characteristics of a soy-yogurt product. Food Hydrocoll. 2009, 23, 490-496. [CrossRef]

44. Geciova, J.; Bury, D.; Jelen, P. Methods for disruption of microbial cells for potential use in the dairy industry-A review. Int. Dairy J. 2002, 12, 541-553. [CrossRef]

45. Pedras, M.M.; Pinho, C.R.G.; Tribst, A.A.L.; Franchi, M.A.; Cristianini, M. The effect of high pressure homogenization on microorganisms in milk. Int. Food Res. J. 2012, 19, 1-5.

46. Middelberg, A.P.J. Process-scale disruption of microorganisms. Biotechnol. Adv. 1995, 13, 491-551. [CrossRef]

47. Dumay, E.; Chevalier-Lucia, D.; Picart-Palmade, L.; Benzaria, A.; Gràcia-Julià, A.; Blayo, C. Technological aspects and potential applications of (ultra) high-pressure homogenisation. Trends Food Sci. Technol. 2013, 31, 13-26. [CrossRef]

48. Liu, H.-H.; Chien, J.-T.; Kuo, M.-I. Ultra high pressure homogenized soy flour for tofu making. Food Hydrocoll. 2013, 32, 278-285. [CrossRef]

49. Rodriguez, C.; Alaswad, A.; El-Hassan, Z.; Olabi, A.G. Mechanical pretreatment of waste paper for biogas production. Waste Manag. 2017, 68, 157-164. [CrossRef] [PubMed]

50. Samarasinghe, N.; Fernando, S.; Lacey, R.; Faulkner, W.B. Algal cell rupture using high pressure homogenization as a prelude to oil extraction. Renew. Energy 2012, 48, 300-308. [CrossRef]

51. Onyeche, T. Economic Benefits of Low Pressure Sludge Homogenization for Wastewater Treatment Plants. In Proceedings of the Moving forward Wastewater Biosolids Sustainability: Technical, Managerial, and Public Synergy, Moncton, NB, Canada, 24-27 June 2007; pp. 417-422.

52. Prabakaran, P.; Ravindran, A.D. A comparative study on effective cell disruption methods for lipid extraction from microalgae. Lett. Appl. Microbiol. 2011, 53, 150-154. [CrossRef] [PubMed]

53. Lee, A.K.; Lewis, D.M.; Ashman, P.J. Disruption of microalgal cells for the extraction of lipids for biofuels: Processes and specific energy requirements. Biomass Bioenergy 2012, 46, 89-101. [CrossRef]

54. Halim, R.; Harun, R.; Danquah, M.K.; Webley, P.A. Microalgal cell disruption for biofuel development. Appl. Energy 2012, 91, 116-121. [CrossRef]

55. Clarke, A.; Prescott, T.; Khan, A.; Olabi, A.G. Causes of breakage and disruption in a homogeniser. Appl. Energy 2010, 87, 3680-3690. [CrossRef]

56. Refaat, A.A.; Sheltawy, S.T.E.; Sadek, K.U. Optimum reaction time, performance and exhaust emissions of biodiesel produced by microwave irradiation. Environ. Sci. Technol. 2008, 5, 315-322. [CrossRef]

57. Im, H.; Lee, H.; Park, M.S.; Yang, J.-W.; Lee, J.W. Concurrent extraction and reaction for the production of biodiesel from wet microalgae. Bioresour. Technol. 2014, 152, 534-537. [CrossRef] [PubMed]

58. Religia, P.; Wijanarko, A. Utilization of n-Hexane as Co-solvent to Increase Biodiesel Yield on Direct Transesterification Reaction from Marine Microalgae. Procedia Environ. Sci. 2015, 23, 412-420. [CrossRef]

59. Cheng, J.; Huang, R.; Li, T.; Zhou, J.; Cen, K. Biodiesel from wet microalgae: Extraction with hexane after the microwave-assisted transesterification of lipids. Bioresour. Technol. 2014, 170, 69-75. [CrossRef] [PubMed]

60. Patil, P.D.; Gude, V.G.; Mannarswamy, A.; Cooke, P.; Munson-McGee, S.; Nirmalakhandan, N.; Lammers, P.; Deng, S. Optimization of microwave-assisted transesterification of dry algal biomass using response surface methodology. Bioresour. Technol. 2011, 102, 1399-1405. [CrossRef] [PubMed]

61. Lee, S.B.; Lee, J.D.; Hong, I.K. Ultrasonic energy effect on vegetable oil based biodiesel synthetic process. J. Ind. Eng. Chem. 2011, 17, 138-143. [CrossRef]

62. Gimbun, J.; Ali, S.; Kanwal, C.C.S.C.; Shah, L.A.; Ghazali, N.H.M.; Cheng, C.K.; Nurdin, S. Biodiesel Production from Rubber Seed Oil using Activated Cement Clinker as Catalyst. Procedia Eng. 2013, 53, 13-19. [CrossRef]

63. Lin, C.; Hsiao, M.; Liao, P. Ultrasonic-Assisted Production of Biodiesel from Waste Frying Oil Using a Two-Step Catalyzing Process. J. Sustain. Bioenergy Syst. 2012, 2012, 117-121. [CrossRef]

64. Cui, Y.; Liang, Y. Direct transesterification of wet Cryptococcus curvatus cells to biodiesel through use of microwave irradiation. Appl. Energy 2014, 119, 438-444. [CrossRef]

65. Martinez-Guerra, E.; Gude, V.G.; Mondala, A.; Holmes, W.; Hernandez, R. Microwave and ultrasound enhanced extractive-transesterification of algal lipids. Appl. Energy 2014, 129, 354-363. [CrossRef]

66. Luo, J.; Fang, Z.; Smith, R.L. Ultrasound-enhanced conversion of biomass to biofuels. Prog. Energy Combust. Sci. 2014, 41, 56-93. [CrossRef] 
67. Hidalgo, P.; Toro, C.; Ciudad, G.; Navia, R. Advances in direct transesterification of microalgal biomass for biodiesel production. Rev. Environ. Sci. Biotechnol. 2013, 12, 179-199. [CrossRef]

68. Wahidin, S.; Idris, A.; Shaleh, S.R.M. Rapid biodiesel production using wet microalgae via microwave irradiation. Energy Convers. Manag. 2014, 84, 227-233. [CrossRef]

69. Soetaredjo, F.E.; Ayucitra, A.; Ismadji, S.; Maukar, A.L. KOH/bentonite catalysts for transesterification of palm oil to biodiesel. Appl. Clay Sci. 2011, 53, 341-346. [CrossRef]

70. Chandra, R.; Goswami, D.; Biotech, E. Scenedesmus dimorphus and Scenedesmus quadricauda: Two potent indigenous microalgae strains for biomass production and $\mathrm{CO}_{2}$ mitigation-A study on their growth behavior and lipid productivity under different concentration of urea as nitrogen source. J. Algal Biomass Utln. 2011, 2, 42-49.

71. Rodriguez, C.; Alaswad, A.; El-Hassan, Z.; Olabi, A.G. Improvement of methane production from P. canaliculata through mechanical pretreatment. Renew. Energy 2017, 119, 73-78. [CrossRef]

72. Alaswad, A.; Olabi, A.G.; Benyounis, K.Y. Integration of finite element analysis and design of experiments to analyse the geometrical factors in bi-layered tube hydroforming. Mater. Des. 2011, 32, 838-850. [CrossRef]

73. Carton, J.G.; Olabi, A.G. Design of experiment study of the parameters that affect performance of three flow plate configurations of a proton exchange membrane fuel cell. Energy 2010, 35, 2796-2806. [CrossRef]

(C) 2018 by the authors. Licensee MDPI, Basel, Switzerland. This article is an open access article distributed under the terms and conditions of the Creative Commons Attribution (CC BY) license (http:/ / creativecommons.org/licenses/by/4.0/). 